\title{
Dietary practices and associated factors during pregnancy in northwestern Ethiopia

Amanuel Nana ${ }^{1 *}$ and Tona Zema ${ }^{2}$

\begin{abstract}
Background: Pregnancy is the most crucial nutritionally demanding period of every woman's life. The high demand of nutrients to deposit energy in the form of new tissue, growth of existing maternal tissues such as breast and uterus and increased energy requirements for tissue synthesis makes pregnant women more vulnerable to malnutrition. Dietary practice is defined as an observable actions or behavior of dietary habit and can be classified as good dietary practices and poor dietary practices. The incidence of dietary inadequacies as a result of dietary habits and patterns in pregnancy is higher during pregnancy when compared to any other stage of the life cycle. Thus, this study aimed to assess dietary practices and associated factors during pregnancy in Bahir Dar town, Northwest Ethiopia.

Methods: A community based cross sectional study was conducted from March 1 to April 1, 2016. A total of 616 pregnant women were participated in the study. All eligible pregnant women were identified through house-to-house visit with the help of health extension workers. Cluster sampling was used to select eligible pregnant women. The data were collected using interviewer administered questionnaire prepared in English and translated in to Amharic. Data were analyzed by using Statistical Package for Social Sciences (SPSS) version 20. Multivariate logistic regression analysis was employed to identify factors associated with dietary practices.

Result: This study has shown that $39.3 \%$ of the study participants had good dietary practices and the rest $60.7 \%$ of pregnant women reported poor dietary practices. Concerning dietary knowledge, $61.4 \%$ of the study participants had good dietary knowledge while $38.6 \%$ had poor dietary knowledge. Husband income, ownership of radio, history of disease and dietary knowledge were shown to have significant association $(P<0.05)$ with dietary practices.

Conclusion: Dietary practices of pregnant women in the study area was suboptimal. Husband income, ownership of radio, history of disease and dietary knowledge were independent predictors of women dietary practices. Awareness should be created among pregnant women by concerned bodies such as governmental and non-governmental organization through local mass media.
\end{abstract}

\section{Background}

Pregnancy is the most crucial nutritionally demanding period of every woman's life. The high demand of nutrients to deposit energy in the form of new tissue, growth of existing maternal tissues such as breast and uterus and increased energy requirements for tissue synthesis makes pregnant women more vulnerable to malnutrition [1].

In 2010, maternal and child undernutrition was responsible for 1.5 million mortalities in the world [2]. A serious problem of maternal under nutrition is evident in most countries in sub-Saharan Africa, South-central

\footnotetext{
* Correspondence: amannana18@gmail.com

${ }^{1}$ Faculty of Chemical and Food Engineering, Bahir Dar Institute of

Technology, Bahir Dar University, Bahir Dar, Ethiopia

Full list of author information is available at the end of the article
}

and Southeastern Asia [3]. Ethiopia is one of the countries with very high burden of maternal and child under nutrition. Based on 2014 Ethiopian democratic and health survey (EDHS), maternal mortality (number of deaths per 100,000 live born) was $25.1 \%$ [4]. In 2011, $27 \%$ of Ethiopian women were undernourished and it is 29.8\% in Amhara region where current study was conducted. Moreover, 23\% of Ethiopian women aged 1549 are anemic and 1\% having severe anemia [5]. Malnutrition during pregnancy yield both short and longterm effects on the health of an infant by programming the infant's development [6] and associated with risk of non-communicable diseases such as obesity, type 2 diabetes, hypertension and cardiovascular disease in later life [7]. Malnourished mothers are more vulnerable to

(c) The Author(s). 2018 Open Access This article is distributed under the terms of the Creative Commons Attribution 4.0 International License (http://creativecommons.org/licenses/by/4.0/), which permits unrestricted use, distribution, and 
diseases, encounter more miscarriages and give birth to underweight children whose survival is at risk $[8,9]$.

Pregnant women must get all essential nutrients and gain sufficient weight, the two main modifiable risk factors influencing maternal and infant outcomes [10]. Appropriate nutrition and weight gain benefits pregnant women to meet the demands of her offspring, her own body needs, and to prepare her body for lactation [11]. Low weight gain during pregnancy is risk factors for the delivery of infants too small for gestational age leading to neonatal mortality and morbidity [12], failure to grow, slow cognitive development and chronic diseases in adulthood [13].

Dietary practice is defined as observable actions or behavior of dietary habit and can be classified as having good dietary practices and poor dietary practices. The incidence of dietary inadequacies as a result of dietary habits and patterns in pregnancy is higher during pregnancy when compared to any other stage of the life cycle. Different scholars discovered that many women in developing countries restrict their food intake during pregnancy for different reasons such as to have smaller infants because smaller infants will carry a lower risk of delivery complications [14], cultural reason and perceived severity of delivery complications because big babies make delivery difficult $[15,16]$. Thus, low intake of essential nutrients such as protein, energy, vitamins C, Vitamin A and iron due to inappropriate nutrition practices together with environmental factors, socioeconomic factors and infections are common causes of maternal mortality, low birth weight and intrauterine growth retardation $[17,18]$.

Even though the existence of government health sector development programs, it was recognized that poor nutritional status of children and women continues to be a serious problem in Ethiopia. Limited studies explored factors influencing maternal dietary practices in different parts of the country. For instance, exposure to nutrition information, attitude towards specific dietary habits and nutrition knowledge [19], attending antenatal care [20], maternal education and income $[19,20]$ were explored as predictors of maternal dietary practices. In addition, age at first marriage, meal frequency [21], educational status [22], occupation of head of household, religion [23], maternal age and marital status [22, 23], were discovered as predictors of maternal nutritional status which in turn influence dietary practices of mothers. Identifying specific factors affecting maternal dietary practice is necessary and critical to design right intervention. Thus, this study was aimed to assess dietary practices and associated factors of pregnant women in Bahir Dar town, Northwest Ethiopia.

\section{Methods}

\section{Study settings, design and period}

A community based cross-sectional study was employed from March 1-April 1, 2016 in Bahir Dar town, northwest Ethiopia. The town is located $565 \mathrm{~km}$ Northwest of Addis Ababa, the capital of Ethiopia. Based on the 2015 population projection, the town has total population of 243,300 of which 8262 (3.4\%) were pregnant women. In the town, there are 10 government health centers, one referral hospital and many private health facilities. The town has a latitude of $11^{\circ} 36^{\prime} \mathrm{N} 37^{\circ} 23^{\prime} \mathrm{E}$, longitude of $11^{\circ}$ $36^{\prime} \mathrm{N} 37^{\circ} 23^{\prime} \mathrm{E}$ and an elevation of about $1800 \mathrm{~m}$ $(5,906 \mathrm{ft})$ above sea level.

\section{Source population and study population}

The source population was all pregnant women who resided in Bahir Dar town during the study period. The study population was all pregnant women who lived in randomly selected sub cities.

\section{Sample size and sampling techniques}

The sample size was calculated using single population proportion formula. Sample size determination was based on previous research finding of prevalence of poor dietary practices (59.9\%) during pregnancy in Gondar town, Northwest Ethiopia [19]. Using margin of error $(0.05)$, critical value at $95 \%$ confidence level $\left(Z_{1-\alpha / 2}=1.96\right)$, design effect $(\mathrm{DE}=1.5)$ and non-response rate $(10 \%)$, the total sample size calculated based on statistical formula was 611. Even though calculated sample size was 611, the investigators included a total of 616 pregnant women lived in the three selected sub cities so as to not miss additional 5 women in the area. Among nine sub cities (clusters) in Bahir Dar town, three sub cities were selected by simple random sampling method. All eligible pregnant women were identified through house-to-house visit with the help of health extension workers. No pregnant women were excluded since they were apparently healthy (self-reported) and had no disability problem at the time of data collection. Thus, all pregnant women who lived in the three selected clusters were included.

\section{Data collection tools and procedures}

The data were collected using structured interviewer administered questionnaire by six trained diploma nurses. Socio-demographic and socio-economic factors, obstetric factors, dietary knowledge, dietary practices and mid upper arm circumference (MUAC) were assessed.

Questionnaire for evaluating dietary practices was adopted from English published articles and contextualized to local situations. Ten questions were used to assess dietary practices. The score of dietary practices was obtained by summation of responses of each question. Each question was given one mark if the answers were 
correct, favorable or healthy for dietary practices. Zero score was given if the responses were wrong, unfavorable or unhealthy for dietary practices. Study participants were classified to have poor dietary practices if they correctly answer $<75 \%$ of practice questions and good dietary practices if they correctly answer $\geq 75 \%$ of questions $[24,25]$. Dietary knowledge of pregnant women was assessed by constructing 10 questions which were assumed to assess dietary knowledge of pregnant women on the aspects of nutrition required during pregnancy. Similar questions were used by previous study in Guto Gida district of Oromia region and this study adopted some of them [26].

Nutrition status of pregnant women was determined by using non-stretchable measuring tape made for measuring MUAC of adults. MUAC value of the left arm was taken to nearest $0.1 \mathrm{~cm}$ with no clothing on the arm and done in triplicate for each respondent in order to ensure accuracy [27]. Respondents were classified as undernourished (MUAC $<23 \mathrm{~cm}$ ) and normal (MUAC $\geq 23 \mathrm{~cm}$ ) [28].

\section{Data quality assurance, processing and analysis}

Questionnaire was first prepared in English, translated to local language (Amharic) and then re-translated back to English to keep consistency. Two days training was given to data collectors and supervisor. The questionnaire was pre-tested on $5 \%$ of the actual sample size. Data were monitored and checked for completeness on daily basis during data collection. The data were coded, checked for any missing and entered into Epi-Info version 7 and then exported to Statistical Package for Social Sciences (SPSS) version 20.0 for analysis. Continuous data were checked for normality using KolmogrovSmirnov test. Descriptive statistics such as frequency, percentage, mean and standard deviation were generated. Bivariate analysis was employed to identify factors associated with dietary practices. Variables with $p$-value less than 0.2 in bivariate analysis were entered into multivariate analysis as it controls confounders. The association between dietary practices and independent variables were determined using crude odd ratio (COR) and adjusted odds ratio (AOR) at 95\% confidence interval and variables with probability value ( $\mathrm{p}$-value) less than 0 . 05 were considered as statistically significant predictor of dietary practices.

\section{Results}

Socio demographic and socioeconomic characteristics of the study participants

A total of 616 pregnant women participated in this study making the response rate $100 \%$. The mean age of study participants was $28.79 \pm 5.13$. About $36.4 \%$ of study participants were between age ranges of 25-29. Majority (94.5\%) were Amhara by ethnicity. Four hundred seventy-three $(76.8 \%)$ were orthodox by religion. Ninetyeight percent of the participants were married. Concerning education status, (37.5\%) were attained secondary school (9-12). Forty-two percent of study participants were house wives and only $12 \%$ were involved in other works. More than half (54.2\%) of the participants earn on average less than 1000 Ethiopian birr (ETB). Majority (93.8\%) of participants reported that monetary decisions made by husband and wife together. Average family size in this study was $3.45 \pm 1.25$ individuals and majority (81.3\%) has family size greater than 4 . About 97.4, 83.1 and $86.0 \%$ of participants have mobile phone, radio and television respectively (Table 1 ).

\section{Obstetric and pregnancy related characteristics of the study participants}

Concerning obstetric and pregnancy related characteristics, more than half $(53.7 \%)$ of women were at third trimester followed by $40.1 \%$ of women who were at second trimester. With regard to women's previous pregnancies, about 549 (89.1\%) of women had 0-2 previous pregnancies. Concerning number of times, a women gave birth to child, $52.9 \%$ of women had less than 2 parities. Sixty-four percent of women had more than 5-years pregnancy interval whereas only $2.4 \%$ had less than 2 -years pregnancy interval. As far as experiencing illness is concerned during pregnancy, 36.5\% of women experienced certain illness a month prior to the survey (Table 2).

\section{Dietary knowledge of study participants}

In this study, 378(61.4\%) of the study participants had good dietary knowledge and 238(38.6\%) had poor dietary knowledge. Specifically, except for the knowledge about iodine source foods $(48.7 \%)$, vitamin A source foods (64.1\%) and iron source foods (60.4\%), all other knowledge variables scored $\geq 75 \%$ indicating good dietary knowledge (Table 3).

\section{Dietary practices of the study participants}

Dietary practices of study participants were indicated in Table 4. The result indicated that 203(33\%) study participants avoid certain foods, of which $74.4 \%$ avoids food due to religious reason. About $61.7 \%$ skip their usual meal and the most commonly skipped meal was breakfast. From 436 (70.8\%) who took an additional meal; $210(48.17 \%)$ and $217(49.77 \%)$ took one and two additional meals respectively. Concerning consumption of macro and micro nutrient source foods 41.7, 38.8, and $77.4 \%$, were consuming carbohydrate, protein and vitamin rich foods like fresh vegetables respectively. About three fourth $(75.3 \%)$ of the study participants had practiced checking weight in current pregnancy. Generally, majority $(60.7 \%)$ of the study participants had poor 
Table 1 Socio-demographic and socio-economic characteristics of the pregnant women in Bahir Dar town, Northwest Ethiopia, $2016(n=616)$

\begin{tabular}{|c|c|c|c|}
\hline Variable & & Frequency (N) & Percent (\%) \\
\hline \multirow[t]{4}{*}{ Age } & $19-24$ & 138 & 22.4 \\
\hline & $25-29$ & 224 & 36.4 \\
\hline & $30-34$ & 168 & 27.3 \\
\hline & $>35$ & 86 & 14.0 \\
\hline \multirow[t]{2}{*}{ Ethnicity } & Amhara & 582 & 94.5 \\
\hline & Others $^{a}$ & 34 & 5.5 \\
\hline \multirow[t]{3}{*}{ Religion } & Orthodox & 473 & 81.3 \\
\hline & Muslim & 115 & 18.7 \\
\hline & $\begin{array}{l}\text { Protestant, } \\
\text { Catholic and } \\
\text { Adventists }\end{array}$ & 28 & 4.5 \\
\hline \multirow[t]{5}{*}{ Education status } & $\begin{array}{l}\text { Unable to read } \\
\text { and write }\end{array}$ & 34 & 5.5 \\
\hline & Read and write & 62 & 10.1 \\
\hline & Grade 1-8 & 98 & 15.9 \\
\hline & Grade 9-12 & 231 & 37.5 \\
\hline & Higher institution & 191 & 31.0 \\
\hline \multirow{4}{*}{$\begin{array}{l}\text { Respondent } \\
\text { occupation }\end{array}$} & House wife & 260 & 42.2 \\
\hline & Employed & 135 & 21.9 \\
\hline & Merchant & 146 & 23.7 \\
\hline & Other ${ }^{b}$ & 75 & 12.2 \\
\hline \multirow{3}{*}{$\begin{array}{l}\text { Respondent } \\
\text { monthly income } \\
\text { (in Ethiopian Birr) }\end{array}$} & $<1000$ & 334 & 54.2 \\
\hline & $1000-2000$ & 137 & 22.2 \\
\hline & $>2000$ & 145 & 23.5 \\
\hline \multirow[t]{2}{*}{ Marital status } & Married & 604 & 98.1 \\
\hline & $\begin{array}{l}\text { Single/Divorced/ } \\
\text { widowed }\end{array}$ & 12 & 1.9 \\
\hline \multirow[t]{2}{*}{ Head of household } & Husband & 603 & 97.9 \\
\hline & Others ${ }^{c}$ & 13 & 2.1 \\
\hline \multirow[t]{4}{*}{ Husband occupation } & Employed & 235 & 38.1 \\
\hline & Merchant & 253 & 41.1 \\
\hline & Daily laborer & 59 & 9.6 \\
\hline & Others $^{d}$ & 69 & 11.2 \\
\hline \multirow[t]{3}{*}{ Husband income (ETB) } & $<1000$ & 162 & 26.3 \\
\hline & $1000-2000$ & 339 & 55 \\
\hline & $>2000$ & 115 & 18.7 \\
\hline \multirow[t]{2}{*}{$\begin{array}{l}\text { Monetary decision } \\
\text { maker }\end{array}$} & $\begin{array}{l}\text { Husband and } \\
\text { wife together }\end{array}$ & 578 & 93.8 \\
\hline & Others ${ }^{\mathrm{e}}$ & 38 & 6.2 \\
\hline \multirow[t]{2}{*}{ Family size } & Less than 4 & 501 & 81.3 \\
\hline & More than 4 & 115 & 18.7 \\
\hline Mobile & Yes & 600 & 97.4 \\
\hline Radio & Yes & 512 & 83.1 \\
\hline
\end{tabular}

Table 1 Socio-demographic and socio-economic characteristics of the pregnant women in Bahir Dar town, Northwest Ethiopia, 2016 ( $n=616)$ (Continued)

\begin{tabular}{llll}
\hline Variable & & Frequency (N) & Percent (\%) \\
\hline TV & Yes & 530 & 86.0 \\
Laptop & Yes & 100 & 16.2 \\
\hline
\end{tabular}

aTigre, Oromo, Awi; ' daily labor/private; ' wife, grandfather, grandmother;

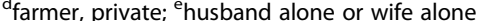

dietary practices and the remaining $39.3 \%$ of the study participants had good dietary practices (Table 4).

Factors associated with dietary practices of pregnant women In multivariate logistic regression analysis, husband income, ownership of radio, history of illness and dietary knowledge revealed significant association with dietary practices $(P<0.05)$. Those study participants whose husbands earn 1000-2000 ETB per month were 2.8 times more likely to have good dietary practice than those earning less than $1000 \mathrm{ETB}(\mathrm{AOR}=2.84,95 \% \mathrm{CI}, 1.74,4.62)$ where as women whose husbands earn more than 2000 ETB were 3.1 times more likely to have good dietary practice than those earning less than $1000 \mathrm{ETB}(\mathrm{AOR}=3.12$, 95\% CI, 1.743, 5.586).

The study participants who own radio were 3.17 times more likely to have good dietary practices than their counterparts $(\mathrm{AOR}=3.17,95 \% \mathrm{CI}, 1.76,5.67)$. Relative to women experienced illness; women who didn't experience illness were 1.7 times more likely to have good

Table 2 Obstetric and related characteristics of the pregnant women in Bahir Dar town, Northwest Ethiopia, $2016(n=616)$

\begin{tabular}{lll}
\hline Variables & Frequency $(\mathrm{N})$ & Percent (\%) \\
\hline Trimester & 38 & 6.2 \\
First & 247 & 40.1 \\
Second & 333 & 53.7 \\
Third & & \\
Previous pregnancy & 549 & 89.1 \\
$0-2$ & 67 & 10.9 \\
$3-5$ & & \\
Parity ( $n=427)$ & 226 & 52.9 \\
$<2$ & 153 & 35.8 \\
$2-5$ & 48 & 11.3 \\
$>5$ & & \\
Pregnancy interval $(n=427)$ & & 2.4 \\
$<2$ years & 10 & 33.5 \\
$3-5$ years & 143 & 64.1 \\
$>5$ years & 274 & 36.5 \\
History of illness & & 63.5 \\
Yes & 225 & \\
No & 391 & \\
\hline
\end{tabular}


Table 3 Dietary knowledge of the pregnant women in Bahir Dar town, Northwest Ethiopia, 2016 $(n=616)$

\begin{tabular}{|c|c|c|c|c|}
\hline \multirow[t]{2}{*}{ Questions (statements)/variables } & \multicolumn{2}{|l|}{ Yes } & \multicolumn{2}{|l|}{ No } \\
\hline & \# & $\%$ & \# & (\%) \\
\hline Food is important for growth and development of fetus. & 610 & 99 & 6 & 1 \\
\hline Food is important for providing heat, energy and for the normal functioning of women's body. & 605 & 98.2 & 11 & 1.8 \\
\hline Food is important for fighting infection or disease. & 605 & 98.2 & 11 & 1.8 \\
\hline Knowledge about balanced diet & 510 & 82.8 & 106 & 17.2 \\
\hline Inadequate diet can cause miscarriage and still birth. & 422 & 68.5 & 194 & 31.5 \\
\hline Knowledge about carbohydrate source foods & 463 & 75.2 & 153 & 24.8 \\
\hline Knowledge about protein source foods & 487 & 79.1 & 129 & 20.9 \\
\hline Knowledge about iron source foods & 372 & 60.4 & 244 & 39.6 \\
\hline Knowledge about vitamin A source foods & 395 & 64.1 & 221 & 35.9 \\
\hline Knowledge about lodine source foods & 300 & 48.7 & 316 & 51.3 \\
\hline \multirow[t]{2}{*}{ Knowledge status } & \multicolumn{3}{|c|}{ Good (score $\geq 75 \%$ ) 378} & $61.4 \%$ \\
\hline & \multicolumn{3}{|c|}{ Poor (score < 75\%) 238} & $38.6 \%$ \\
\hline
\end{tabular}

Source: [26]

dietary practices $(\mathrm{AOR}=1.73,95 \% \mathrm{CI}, 1.17,2.56)$. The study participants who have good dietary knowledge were 3.86 times more likely to have good dietary practice than their counterparts $(\mathrm{AOR}=3.86,95 \% \mathrm{CI}, 1.91,4.29)$ (Table 5).

\section{Discussion}

Maternal dietary practices during pregnancy play an important role in determining the long-term health and nutritional status of both the mother and her growing fetus. Poor dietary practices during pregnancy may result in increased rates of stillbirths, premature birth, low birth weight, maternal and prenatal death. In this study only $39.3 \%$ of the study participants had good dietary practices. This figure is nearly similar with study in Gondar town, northwest Ethiopia [19], but slightly higher than study in Guto Gida district, western Ethiopia [16]. The differences in dietary practices among studies, particularly modest improvement in dietary practices may be due to Ethiopian government is currently promoting nutrition related interventions through health extension program, health facility nutrition services, community-based women development army program and active involvement of pregnant women in focused antenatal care as well as in one-five network meeting at community level.

Even though health sectors developing different health and nutrition programs, this result have shown that poor dietary practices during pregnancy is still problem in Ethiopia. In current study, maternal nutrition regarding specific dietary practices such as skipping usual diets, avoiding certain food items and consumption of fresh fruits and vegetables were sub optimal. Avoiding food in pregnancy repeatedly reported by pregnant women. In this study more than one third of the study participants reported to avoid food during pregnancy. This finding is in line with other study in Oromia region, western Ethiopia [16]. On the contrary, this study indicated lower prevalence of skipping meal, avoiding foods, taking no additional meals during pregnancy and consumption of fruits and vegetables compared to study in Wondo Genet district, southern Ethiopia [15]. The discrepancy might be attributable to differences in sample size, geographical location, socio-economic characteristics and cultural differences. It is also repeatedly reported that dietary practices can be influenced by culture, socioeconomic and environmental determinants $[18,29,30]$. Low prevalence of avoiding food due to cultural reason reported in this study was consistent with studies in Wondo Genet district, southern Ethiopia [15]; but it is in contrary with previous studies in Guto Gida district, Gondar town and Shashemene district [16, 19, 20]. This may also be attributed to differences in sample size, geographical location and socio-cultural differences. This may be because of what is taboo (culture) in one society is not taboo in other society particularly when the society is very diverse.

In this study, husband's income was significantly associated with dietary practices of pregnant women. This might be due to the fact that, the more husband earns, the more he invests on family nutrition and health which in turn attributes to good dietary practices of family in general and pregnant women in particular. Furthermore, earnings can influence availability of resources which in turn improve access to a diversified diet and thus improve dietary practices. This study is in line with other studies which also reported that income has positive significant association with women dietary practices [19, 31]. 
Table 4 Dietary practices of the pregnant women in Bahir Dar town, Northwestern Ethiopia, 2016 $(n=616)$

\begin{tabular}{|c|c|c|c|}
\hline Questions/variables & & $\begin{array}{l}\text { Number } \\
(n=616)\end{array}$ & Percentage (\%) \\
\hline \multirow{2}{*}{$\begin{array}{l}\text { Avoid any food or diet } \\
\text { in the current pregnancy }\end{array}$} & Yes & 203 & 33.0 \\
\hline & No & 413 & 67.0 \\
\hline \multirow[t]{5}{*}{ Reasons of avoiding } & Religion & 151 & 74.38 \\
\hline & Culture & 2 & 1.0 \\
\hline & To avoid big baby & 17 & 8.37 \\
\hline & Labor difficulty & 6 & 2.95 \\
\hline & $\begin{array}{l}\text { Others } \\
\text { (dislike, discomfort) }\end{array}$ & 27 & 13.30 \\
\hline \multirow{2}{*}{$\begin{array}{l}\text { Dietary regimen during } \\
\text { current pregnancy }\end{array}$} & Yes & 414 & 67.2 \\
\hline & No & 202 & 32.8 \\
\hline \multirow{2}{*}{$\begin{array}{l}\text { Skipping meal during } \\
\text { current pregnancy }\end{array}$} & Yes & 380 & 61.7 \\
\hline & No & 236 & 38.3 \\
\hline \multirow[t]{4}{*}{ Type of meal skipped } & Breakfast & 266 & 70 \\
\hline & Lunch & 6 & 1.6 \\
\hline & Snack & 93 & 24.5 \\
\hline & Dinner & 15 & 3.9 \\
\hline \multirow[t]{2}{*}{ Taking additional meal } & Yes & 436 & 70.8 \\
\hline & No & 180 & 29.2 \\
\hline \multirow{3}{*}{$\begin{array}{l}\text { Number of additional } \\
\text { meals }\end{array}$} & 1.One & 210 & 48.17 \\
\hline & 2. Two & 217 & 49.77 \\
\hline & 3. Three and more & 9 & 2.06 \\
\hline \multirow[t]{2}{*}{ Took iron supplement } & Yes & 400 & 64.9 \\
\hline & No & 216 & 35.1 \\
\hline \multirow{2}{*}{$\begin{array}{l}\text { Habits of eating snacks } \\
\text { between meals }\end{array}$} & Yes & 494 & 80.2 \\
\hline & No & 122 & 19.8 \\
\hline \multirow{2}{*}{$\begin{array}{l}\text { Consumption/eating } \\
\mathrm{CHO} \text { rich foods daily }\end{array}$} & Yes & 257 & 41.7 \\
\hline & No & 359 & 58.3 \\
\hline \multirow{2}{*}{$\begin{array}{l}\text { Consumption/eating } \\
\text { protein rich foods daily }\end{array}$} & Yes & 293 & 38.8 \\
\hline & No & 377 & 61.2 \\
\hline \multirow{2}{*}{$\begin{array}{l}\text { Consumption/eating } \\
\text { fresh vegetables daily }\end{array}$} & Yes & 477 & 77.4 \\
\hline & No & 139 & 22.6 \\
\hline \multirow{2}{*}{$\begin{array}{l}\text { Consumption/eating } \\
\text { fruits daily }\end{array}$} & Yes & 429 & 69.6 \\
\hline & No & 187 & 30.4 \\
\hline \multirow{3}{*}{$\begin{array}{l}\text { Following weight } \\
\text { during pregnancy }\end{array}$} & Yes & 464 & 75.3 \\
\hline & No & 152 & 24.7 \\
\hline & $\begin{array}{l}\text { Good } \\
\text { (score } \geq 75 \%)\end{array}$ & 242 & 39.3 \\
\hline Overall dietary practices & Poor (score < 75\%) & 374 & 60.7 \\
\hline
\end{tabular}

Present study also revealed that pregnant women having good dietary knowledge were more likely to have good dietary practices compared to women who do not have dietary knowledge. This was also documented by study conducted in Gondar town where nutrition knowledge shown significant association with women dietary practices [19]. One study in America also indicated that women dietary knowledge was predictor of good dietary practices [24]. Statistical significant association, but not strong association between dietary knowledge and dietary practice was also indicated by one study in Singapore [30]. This may have explained as, when a woman had good dietary knowledge, she become more concerned to good dietary practices and immediately can put it in to practice. On the other hand, good knowledge about basic nutrients and balanced diet usually resulting in positive dietary practices which are important determinants of optimum health from conception until death [32].

Current study has revealed that owning radio was significantly associated with women's dietary practices. This might be attributable to owning radio and television would help individuals and families to broadcast important nutrition information such as about good or favorable dietary practices and its importance. Research evidence also suggested that women exposed to nutrition information were more likely to have good dietary practices than women haven't exposed to nutrition information [16]. Present study also documented that women who experience illness were more likely to have poor dietary practices relative to women who didn't experience illness. This might be due to synergistic relationship between diet and disease since infection can decrease appetite and dietary intake as explained in malnutrition-infection vicious cycle.

\section{Conclusion}

In this study only $39.3 \%$ of the study participants had good dietary practice indicating that the overall dietary practice of the pregnant women in Bahir Dar town is suboptimal and the rest $60.7 \%$ of pregnant women reported poor dietary practices. Concerning dietary knowledge, $61.4 \%$ of the study participants had good dietary knowledge while $38.6 \%$ had poor dietary knowledge. Husband's income, dietary knowledge, possessing radio and history of illness were significantly associated with dietary practices of pregnant women in Bahir Dar town, Northwest Ethiopia.

Therefore, increasing household income through providing income generation activities on the behalf of the government should be created. Improving knowledge on nutrition through nutrition education and integrating key nutrition messages in already existing strategy should be strengthened. Furthermore, means of access to radio and television should be created as they can play key role in improvement of dietary practices. Prevention and treatment of illness during pregnancy should also be strengthened. Finally, 
Table 5 Factors associated with dietary practices of the pregnant women in Bahir Dar town, Northwestern Ethiopia, 2016( $n=616)$

\begin{tabular}{|c|c|c|c|c|c|}
\hline \multirow[t]{2}{*}{ Variables } & & \multicolumn{2}{|c|}{ Dietary practices } & \multirow[t]{2}{*}{ COR $(95 \% \mathrm{Cl})$} & \multirow[t]{2}{*}{ AOR(95\%Cl) } \\
\hline & & Good & Poor & & \\
\hline \multirow[t]{3}{*}{ Husband income } & $<1000$ & 38 & 124 & 1 & 1 \\
\hline & $1000-2000$ & 145 & 194 & $2.439(1.599,3.721)^{*}$ & $2.837(1.743,4.618)^{*}$ \\
\hline & $>2000$ & 59 & 56 & $3.438(2.053,5.757)^{*}$ & $3.120(1.743,5.586)^{*}$ \\
\hline \multirow[t]{2}{*}{ Owning radio } & Yes & 223 & 289 & $3.452(2.038,5.848)^{*}$ & $3.168(1.761,5.699)^{*}$ \\
\hline & No & 19 & 85 & 1 & 1 \\
\hline \multirow[t]{2}{*}{ History of illness } & Yes & 72 & 153 & 1 & 1 \\
\hline & No & 170 & 221 & $1.635(1.159,2.306)^{*}$ & $1.734(1.173,2.564)^{*}$ \\
\hline \multirow[t]{2}{*}{ Dietary knowledge } & Good & 187 & 191 & $3.257(1.214,4.441)^{*}$ & $3.864(1.915,4.285)^{*}$ \\
\hline & Poor & 55 & 183 & 1 & 1 \\
\hline
\end{tabular}

*Significant at $p<0.05$

women of child bearing age should be considered and basic education should be strengthened on the behalf of the government.

\section{Limitation of the study}

Lack of standardized questionnaire at national level and failure to assess food intake in terms of specific nutrients consumed.

\section{Abbreviations}

AOR: Adjusted odd ratio; COR: Crude odd ratio; EDHS: Ethiopian demographic and health survey; ETB: Ethiopian birr; SPSS: Statistical package for social sciences

\section{Acknowledgements}

The researchers were thankful to Bahir Dar Institute of Technology for funding this research. We would also like to thank Amhara public health institute for their cooperation and providing permission. We were also grateful to administrative of the three sub cities. Finally, we would like to acknowledge data collectors and study participants for providing all necessary information.

\section{Funding}

Bahir Dar Institute of Technology provided financial support for this research.

\section{Availability of data and materials}

Datasets used and/or analyzed during the current study are available from the corresponding author on reasonable request.

\section{Authors' contributions}

AN carried out the study design, data collection, data management and analysis. TZ participated in study design and data analysis. AN drafted manuscript and $T Z$ revised manuscript. Both authors read and approved the manuscript.

\section{Ethics approval and consent to participate}

Ethical approval was obtained from Bahir Dar University ethical review board. Permission was obtained from Amhara public health institute which was previously known as Amhara regional health laboratory. We made further contact with administrative of the three sub cities (Ginbot 20, Sefene selam and Hidar 11) just before starting data collection. Informed verbal consent was obtained from each study participants.

\section{Competing interests}

The authors declare that they have no competing interests.

\section{Publisher's Note}

Springer Nature remains neutral with regard to jurisdictional claims in published maps and institutional affiliations.

\section{Author details}

${ }^{1}$ Faculty of Chemical and Food Engineering, Bahir Dar Institute of Technology, Bahir Dar University, Bahir Dar, Ethiopia. ${ }^{2}$ School of Nutrition, Food Science and Technology, Hawassa University, Hawassa, Ethiopia.

Received: 2 January 2018 Accepted: 2 May 2018

Published online: 25 May 2018

\section{References}

1. Goldberg G: Nutrition in pregnancy and lactation. Nutrition through the life cycle. Shetty P, ed. Leather head publishing: Leatherhead, UK. 2002, 63-90.

2. Lim SS, Vos T, Flaxman AD, Danaei G, Shibuya K, Adair-Rohani H, et al. A comparative risk assessment of burden of disease and injury attributable to 67 risk factors and risk factor clusters in 21 regions, 2012, 1990-2010: a systematic analysis for the global burden of disease study 2010. Lancet. 2012;380:2224-60

3. Black RE, Allen LH, Bhutta ZA, Caulfield LE, de Onis M, Ezzati M, Mathers C, et al. Maternal and child under nutrition: global and regional exposures and health consequences. Lancet. 2008;371:243-60. https://doi.org/10.1016/ S0140-6736(07)61690-0.

4. Central Statistical Agency [Ethiopia] and ICF International: Ethiopia demographic and health survey. Addis Ababa, Ethiopia, and Calverton, Maryland, USA: Central Statistical Agency and ORC Macro; 2014

5. Central Statistical Agency [Ethiopia] and ICF International: Ethiopia demographic and health survey. Addis Ababa, Ethiopia, and Calverton, Maryland, USA: Central Statistical Agency and ORC Macro; 2012.

6. Isolauri E. Diet, nutrition and nutritional status: from the mother to the infant. The Nest. 2011;31:2-3.

7. Koletzko B, Brands B, Poston L, et al. Early nutrition programming of longterm health. Proceedings of the nutrition. Society. 2012;71:371-8.

8. ACC/SCN: Symposium Report on a Nutrition Policy Discussion Paper on Women and Nutrition: Geneva.1990, 6:27-31.

9. Chasi HC. Infant mortality and weight at birth: 1960 united stated weight cohort. Am J Public Health. 1969:59:1618.

10. Institute of Medicine. Nutrition during pregnancy. Washington: National Academy of Sciences; 1990.

11. Taleb S, Kaibi M, Deghboudj N. Assessment of nutritional status of pregnant women attending the City Tebessa PMI. Natl J Physiol Pharm Pharmacol. 2011;1(2):97-105.

12. K2Kramer MS. Determinants of low birth weight: methodological assessment and meta-analysis. Bull World Health Organ. 1987;65:663-737. PMID:3322602

13. Barker DJ, Gluckman PD, Godfrey KM, Harding JE, Owens JA, Robinson JS. Fetal nutrition and cardiovascular disease in adult life. Lancet. 1993;341:93841. https://doi.org/10.1016/0140 6736(93)91224-A. PMID:8096277

14. Brems S, Berg A: Eating down during pregnancy: nutrition, obstetric and cultural considerations in the third world. Discussion paper prepared for the ACC/ACN. Washington, DC: World Bank; 1988

15. Kuche $D$, Singh $P$, Moges $D$. Dietary practices and associated factors among pregnant women in Wondo Genet District, southern Ethiopia. J Pharm Sci Innov. 2015;4(5):270-5. 
16. Daba G, Beyene F, Fekadu H, Garoma W. Assessment of nutritional practices of pregnant mothers on maternal nutrition and associated factors in Guto Gida Woreda, east Wollega zone, Ethiopia. Sci Technol Arts Res J. 2013;2(3):105-13.

17. Tena M, Bacalo J. Malnutrition and poverty. Ann Rev Nutr. 2002:22:241-53.

18. Madhavi LH, Singh HKG. Nutritional status of rural pregnant women. People's J Sci Res. 2011;4(2):20-3.

19. Alemayehu MS, Tesema EM. Dietary practice and associated factors among pregnant women in Gondar town north west, Ethiopia, 2014. Int J Nutr Food Sci. 2015;4(6):707-12. https://doi.org/10.11648/j.jinfs.20150406.27.

20. Nejimu BZ: Food taboos and misconceptions among pregnant women of Shashemene District, Ethiopia, 2012. Sci J Public Health 2015, 3(3): 410-416 ISSN: 2328-7950.

21. Veronika S, Hans Konrad B, Wang Q, Elizabeth H, Bellows AC. Dietary intake and food habits of pregnant women residing in urban and rural areas of Deyang City, Sichuan Province, China. Nutrients. 2013;5:2933-54. https://doi. org/10.3390/nu5082933.

22. Teller $\mathrm{H}$, Yimar $\mathrm{G}$. Levels and determinants of malnutrition in adolescent and adult women in southern Ethiopia. Ethiop J Health Dev. 2000;14(1):57-66.

23. Central Statistical Authority [Ethiopia] and ORC macro. Ethiopia Demographic and Health Survey 2000.Addis Ababa, Ethiopia, and Calverton. Maryland: Central Statistical Authority and ORC Macro; 2001.

24. Shehab L. Nutritional awareness of women during pregnancy. J Am Sci. 2012;8(7)

25. Shahid Mahrnood MFASS, Mujeeb A, Bano N. Humaira Mubasher: assessment of nutritional beliefs and practices in pregnant and lactating mothers in an urban and rural area of Pakistan; 2015. p. 60-2.

26. Daba G, Beyene F, Fekadu H, Garoma W. Assessment of knowledge of pregnant mothers on maternal nutrition and associated factors in Guto Gida Woreda, east Wollega zone, Ethiopia. J Nutr Food Sci. 2013;3:235. https://doi.org/10.4172/2155-9600.1000235

27. Ververs, M, Antierens A, Sackl A, Staderini N, Captier V (2013). Which anthropometric indicators identify a pregnant woman as acutely malnourished and predict adverse birth outcomes in the humanitarian context?

28. CDC. National health and nutrition examination survey: anthropometry procedures manual. 2007. (June 20-2016): available from https://www.cdc gov/nchs/data/ad/ad361.pdf.

29. Krondl M, Coleman P. Social and biocultural determinants of food selection. Prog Food Nutr Sci. 1986;10:179-203.

30. Mirsanjaril M, Muda D, Ahmad A, Othman MS. Does nutritional knowledge have relationship with healthy dietary attitude and practices during pregnancy? International conference on nutrition and food sciences. IPCBEE 2012, vol. 39. Singapore: IACSIT Press.

31. Jenson j SL, Mary B. Nutrition science \& application. 3rd ed. Tokyo: Saunders Collage publishing; 2003. p. 35-63.

32. Painter J, Rah J, Lee Y. Comparison of international food guide pictorial representation. J Am Diet Assoc. 2003;102(4):483-9.

\section{Ready to submit your research? Choose BMC and benefit from:}

- fast, convenient online submission

- thorough peer review by experienced researchers in your field

- rapid publication on acceptance

- support for research data, including large and complex data types

- gold Open Access which fosters wider collaboration and increased citations

- maximum visibility for your research: over $100 \mathrm{M}$ website views per year

At BMC, research is always in progress.

Learn more biomedcentral.com/submissions 